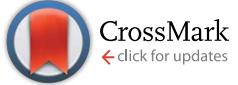

Cite this: Sustainable Energy Fuels, 2017, 1, 626

Received 1st February 2017

Accepted 7th March 2017

DOI: $10.1039 / \mathrm{c} 7 \mathrm{se} 00060 \mathrm{j}$

rsc.li/sustainable-energy

\section{Optimization of performance and long-term stability of p-type dye-sensitized solar cells with a cycloruthenated dye through electrolyte solvent tuning $\dagger$}

\begin{abstract}
Nathalie Marinakis, Markus Willgert, Edwin C. Constable and Catherine E. Housecroft*
p-Type dye sensitized solar cells (DSCs) have been assembled using the structurally unrefined, zwitterionic cyclometallated ruthenium dye $\left[\mathrm{Ru}(\mathrm{bpy})_{2}(\mathrm{H} 1)\right]\left(\mathrm{H}_{3} 1=\right.$ (4-(2-phenylpyridin-4-yl)phenyl)phosphonic acid) in combination with $\mathrm{FTO} / \mathrm{NiO}$ photocathodes and an $\mathrm{I}_{3}^{-} / \mathrm{I}^{-}$/acetonitrile (AN) electrolyte. Values of the shortcircuit current density $\left(J_{\mathrm{SC}}\right)=4.06 \mathrm{~mA} \mathrm{~cm}{ }^{-2}$, open-circuit voltage $\left(V_{\mathrm{OC}}\right)=95 \mathrm{mV}$ and photoconversion efficiency $(\eta)=0.139 \%$ are the highest achieved for state-of-the-art cyclometallated ruthenium dyes in p-type DSCs; data are confirmed using duplicate devices. $J_{S C}$ values are higher than those observed for the standard dye P1, and electrochemical impedance spectroscopy (EIS) shows that DSCs with $\left[\mathrm{Ru}(\mathrm{bpy})_{2}(\mathrm{H} 1)\right]$ exhibit a both a lower transport resistance $\left(R_{\mathrm{t}}\right)$ and recombination resistance $\left(R_{\text {rec }}\right)$ than DSCs with P1. Changing the electrolyte solvent from AN to propionitrile (PN), valeronitrile (VN), 3methoxypropionitrile (MPN) or $N$-methylpyrrolidone (NMP) confirms a dependence of $J_{S C}$ on solvent in the order $\mathrm{AN}>\mathrm{PN}>\mathrm{MPN}>\mathrm{VN}>\mathrm{NMP}$, whilst $V_{\mathrm{OC}}$ follows the trend $\mathrm{VN}>\mathrm{PN}>\mathrm{MPN}>\mathrm{AN}>\mathrm{NMP}$. The opposing trends in $J_{S C}$ and $V_{O C}$ lead to only a small drop in the overall $\eta$ values for PN versus AN. EIS measurements revealed that although $\mathrm{PN}$ has a higher resistance to recombination reactions than $\mathrm{AN}$, it also exhibits an increased amount of trapped charge carriers, leading to worsened DSC performance. DSCs based on AN do not remain stable over a 1-2 month period; both $J_{S C}$ and $V_{O C}$ decrease significantly. However, DSCs with the less volatile and more viscous PN show enhanced performance upon ageing with a gain in $J_{S C}$ over the first 33 days. Electrolytes with mixed solvents were investigated; addition of PN, VN or MPN to AN leads to lower $J_{S C}$ and this is most pronounced for $V N$ and least marked for PN. The optimal solvent is an AN : PN mixture with volume ratios of $3: 1$ or $1: 1$; this mixed solvent results in enhanced long-term stability with respect to DSCS with pure AN and this is at the expense of a only small decrease in photoconversion efficiency.
\end{abstract}

\section{Introduction}

Cyclometallated ruthenium(II) complexes are appealing sensitizers for dye-sensitized solar cells (DSCs). ${ }^{1-3}$ The localization of the highest-occupied molecular orbital (HOMO) of $\mathrm{a}\left[\mathrm{Ru}\left(\mathrm{N}^{\wedge} \mathrm{N}\right)_{2}\left(\mathrm{C}^{\wedge} \mathrm{N}\right)\right]^{+}$complex $\left(\mathrm{N}^{\wedge} \mathrm{N}=\right.$ bidentate $\mathrm{N}, \mathrm{N}^{\prime}$-ligand, $\mathrm{C}^{\wedge} \mathrm{N}$ $=$ cyclometallated $\mathrm{C}, \mathrm{N}$-ligand) on the $\mathrm{Ru} / \mathrm{C}^{\wedge} \mathrm{N}$ domain ${ }^{4}$ permits tuning of the electronic properties of the complex through functionalization of the C,N-ligand. Unlike other classes of sensitizers such as organic dyes or metalloporphyrins, functional group variation of cyclometallated $\left[\mathrm{Ru}\left(\mathrm{N}^{\wedge} \mathrm{N}\right)_{2}\left(\mathrm{C}^{\wedge} \mathrm{N}\right)\right]^{+}$ provides a flexible platform for use in both n- and p-type DSCs. In an $\mathrm{n}$-type DSC, the $\mathrm{C}^{\wedge} \mathrm{N}$ ligand plays an ancillary role

Department of Chemistry, University of Basel, Spitalstrasse 51, CH-4056 Basel, Switzerland. E-mail: catherine.housecroft@unibas.ch

$\dagger$ Electronic supplementary information (ESI) available: Table S1. Additional DSC measurement data and $J-V$ curves for mixed solvents. See DOI: $10.1039 / \mathrm{c} 7 \mathrm{se} 00060 \mathrm{j}$ (electron-pushing in a 'push-pull' dye architecture), whilst in a p-type DSC, the $\mathrm{C}^{\wedge} \mathrm{N}$ domain bears the anchoring unit, typically a carboxylic or phosphonic acid..$^{5-10}$ The optimization of $\left[\mathrm{Ru}\left(\mathrm{N}^{\wedge} \mathrm{N}\right)_{2}\left(\mathrm{C}^{\wedge} \mathrm{N}\right)\right]^{+}$dyes for $\mathrm{p}$-type DSCs (the working principle of which is summarized in Fig. 1) is still in its infancy. Recently, we demonstrated that p-type DSCs with FTO/NiO photocathodes functionalized with the zwitterion $\left[\mathrm{Ru}(\mathrm{bpy})_{2}(\mathrm{H} 1)\right]$ (Scheme 1) as sensitizer achieved short-circuit current densities $\left(J_{\mathrm{sC}}\right)$ of up to $3.38 \mathrm{~mA} \mathrm{~cm}{ }^{-2}$ and photoconversion efficiencies $(\eta)$ of up to $0.116 \%$. These values exceed those measured for the standard dye P1 (ref. 10 and 11) (Scheme 1). Despite the simple molecular architecture of $\left[\mathrm{Ru}(\mathrm{bpy})_{2}(\mathrm{H} \mathbf{1})\right]$, its photoconversion efficiency is comparable with that of the previously reported bestperforming cyclometallated ruthenium(II) dye in p-type DSCs. ${ }^{5}$ Improvement of the performance of p-type DSCs is hindered by rapid recombination of reduced dye molecules and injected holes at the p-type semiconductor/dye interfaces, which militates against efficient dye regeneration at the dye/electrolyte 


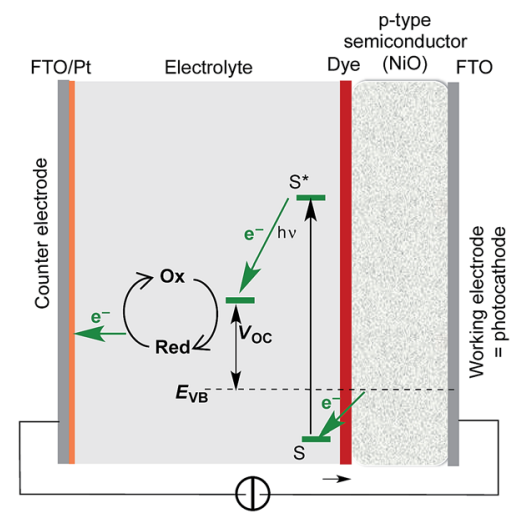

Fig. 1 A diagram showing the working principle of a p-type DSC. S and $S^{*}$ are the ground and excited states of the dye; $E_{\mathrm{VB}}$ signifies the quasiFermi level of the valence band of the semiconductor; $V_{O C}=$ open circuit voltage.

interface. ${ }^{12}$ Hole transport resistance is typically high in p-type DSCs.

In n-type DSCs, it is well established that the choice of solvent in the electrolyte plays a critical role in the device performance and stability. ${ }^{13,14}$ Ideally, the solvent should have a high boiling point to minimize cell degradation through solvent evaporation. Long-term stability of n-type DSCs has been demonstrated with tetraglyme-based $\mathrm{I}_{3}^{-} / \mathrm{I}^{-}$electrolytes. ${ }^{15,16}$ Nonetheless, solvents such as acetonitrile, valeronitrile, propionitrile, butyronitrile, 3-methoxy propionitrile and propylene carbonate remain popular. ${ }^{17,18}$ Acetylacetone may also be a viable solvent in DSCs. ${ }^{19}$ Solvent polarity appears to<smiles>N#CC(C#N)=Cc1ccc(-c2ccc(N(c3ccc(C(=O)O)cc3)c3ccc(-c4ccc(C=C(C#N)C#N)s4)cc3)cc2)s1</smiles><smiles></smiles>

$\left[\mathrm{Ru}(\mathrm{bpy})_{2}(\mathrm{H} 1)\right]$

Scheme 1 Structures of sensitizers P1 and the zwitterion $\left[\mathrm{Ru}(\mathrm{bpy})_{2}(\mathrm{H} 1)\right]$. play a key role, and it is noteworthy that DSC both $J_{\mathrm{SC}}$ and in the open circuit voltage $\left(V_{\mathrm{OC}}\right)$ by manipulation of the solvent polarity. ${ }^{20}$

In p-type DSCs, electrolytes have yet to be optimized. For our initial investigations of DSC performances with $\left[\mathrm{Ru}(\mathrm{bpy})_{2}(\mathrm{H} \mathbf{1})\right]$, we chose to use an $\mathrm{I}_{3}{ }^{-} / \mathrm{I}^{-}$based electrolyte in acetonitrile. ${ }^{10}$ This electrolyte composition has previously been used in liquid p-type DSCs with or without a TBP additive. ${ }^{21-26}$ The use of acetonitrile rather than propylene carbonate $^{27}$ is known to enhance the short-circuit current density. We now report the effects on the performances of $\mathrm{p}$ type DSCs sensitized by $\left[\mathrm{Ru}(\mathrm{bpy})_{2}(\mathrm{H} \mathbf{1})\right]$ of $\mathrm{I}_{3}{ }^{-} / \mathrm{I}^{-}$containing electrolytes in five different solvents. Initially, we assess the effects on $J_{\mathrm{SC}}$ and $V_{\mathrm{OC}}$ (and, hence, ultimately on $\eta$ ) of a change from acetonitrile (AN) to propionitrile (PN), valeronitrile (VN), 3-methoxypropionitrile (MPN) and $N$-methylpyrrolidone (NMP). Some relevant physical properties of these solvents are given in Table 1 . Finally we consider the benefits of using mixed solvents.

\section{Experimental}

\section{Chemical reagents}

All organic solvents were of HPLC high-purity grade. Acetonitrile (AN) was purchased from Macron ${ }^{\mathrm{TM}}$, EtOH from J.T. Baker®, propionitrile (PN), valeronitrile (VN), 3-methoxypropionitrile (MPN), $N$-methyl-2-pyrrolidone (NMP) from ACROS organics, LiI (99.9\%), $\mathrm{I}_{2}$ (99.9\%) from Sigma-Aldrich and $\left[\mathrm{Ni}(\mathrm{acac})_{2}\right]$ from ACROS. The dye P1 was purchased from Dyenamo $A B$ and $\left[\mathrm{Ru}(\mathrm{bpy})_{2}(\mathrm{H} \mathbf{1})\right]$ was prepared as previously described. ${ }^{10}$

\section{NiO electrodes preparation}

Working electrodes were either purchased from Dyenamo (DNS01) or were prepared in-house. For the latter, an FTO glass plate was cleaned by sonicating in surfactant $(2 \%$ in MilliQ water), and rinsed sequentially with MilliQ water and EtOH. The surface was activated in a UV-O $\mathrm{O}_{3}$ system (Model 256-220, Jelight Company Inc) for $20 \mathrm{~min}$. The glass was then immersed five times in a solution (AN $0.5 \mathrm{mM})$ of $\left[\mathrm{Ni}(\mathrm{acac})_{2}\right]$ and air dried after each dipping. A layer of NiO paste (Ni-Nanoxide N/SP, Solaronix) was then screen-printed (90T, Serilith AG, Switzerland) onto the pretreated FTO plate. The plate was placed in an EtOH chamber for $3 \mathrm{~min}$ to reduce surface irregularities, then dried for $6 \mathrm{~min}$ at $125{ }^{\circ} \mathrm{C}$ on a heating plate. The screen printing process was repeated to give two layers. Both the commercial and in-house screen-printed electrodes were sintered by gradually heating from room temperature to $350{ }^{\circ} \mathrm{C}$ over a period of $30 \mathrm{~min}$, kept at $350{ }^{\circ} \mathrm{C}$ for $30 \mathrm{~min}$, then allowed to cool over $\sim 2 \mathrm{~h}$ to room temperature. After this sintering, the FTO/NiO plates were cut to make electrodes $1 \mathrm{~cm} \times 2 \mathrm{~cm}$. After the final sintering, the thickness of the in-house electrode NiO layer was typically 1.9$3.2 \mu \mathrm{m}$ (by FIB measurements, recorded using a REM-FEI Helios Nano Lab 650). The Dyenamo NiO layer had a thickness of $2 \mu \mathrm{m}$ (Dyenamo DN-S01). 
Table 1 Selected properties of solvents used in this work ${ }^{a}$

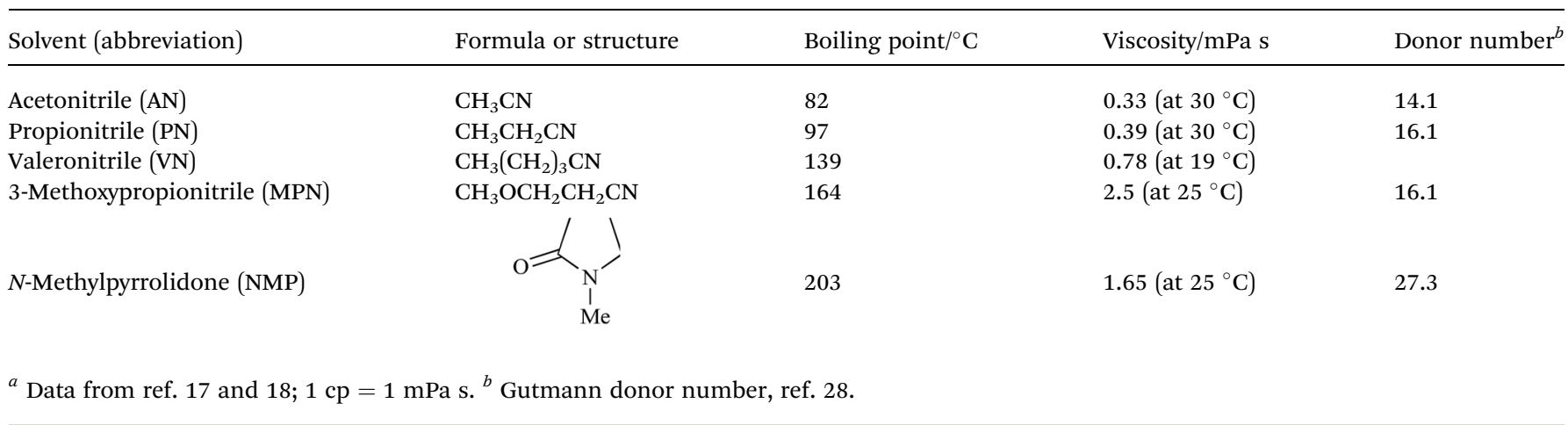

\section{DSC assembly}

The working electrodes were heated at $250{ }^{\circ} \mathrm{C}$ for $20 \mathrm{~min}$ and then cooled to $80{ }^{\circ} \mathrm{C}$ before being immersed in an acetonitrile (AN) solution of P1 $(0.3 \mathrm{mM})$ or EtOH solution of $\left[\mathrm{Ru}(\mathrm{bpy})_{2}(\mathrm{H} 1)\right]$ $(0.1 \mathrm{mM})$ for $20 \mathrm{~h}$. The electrodes were removed from the solutions, washed with EtOH, then dried in an $\mathrm{N}_{2}$ stream. Commercial counter electrodes (Solaronix Test Cell Platinum Electrodes) were washed with $\mathrm{EtOH}$ and then heated at $450{ }^{\circ} \mathrm{C}$ (hot plate) for $30 \mathrm{~min}$ to remove volatile organic impurities.

The DSCs were assembled by combining working and counter electrodes using thermoplast hot-melt sealing foil (Solaronix, Meltonix 1170-25 Series, $60 \mu \mathrm{m}$ thick) by heating while pressing them together. The electrolyte comprised $I_{2}(0.1$ $\mathrm{M})$, LiI ( $1 \mathrm{M}$ ) in varying solvents (see text) and was introduced into the DSC by vacuum backfilling. The hole in the counter electrode was then sealed using a hot-melt sealing foil and cover glass.

\section{Device performance measurements}

The solar cell measurements were made using duplicate unmasked cells; the active area was $0.237 \mathrm{~cm}^{2}$ (in-house electrodes) or $0.25 \mathrm{~cm}^{2}$ (Dyenamo electrodes). The DSCs were sunsoaked from the anode side for $20 \mathrm{~min}$ at 1 sun irradiation. The cell was then inverted and measured immediately with a LOT Quantum Design LS0811 instrument $\left(100 \mathrm{~mW} \mathrm{~cm}^{-2}=1\right.$ sun at AM 1.5 and $23{ }^{\circ} \mathrm{C}$ ) to obtain the current density-voltage
$(J-V)$ curves. The instrument software was set to a p-type measurement mode (inverted configuration), with a $360 \mathrm{~ms}$ settling time, ${ }^{\mathbf{1 0}}$ and a voltage step of $5.3 \mathrm{mV}$. The voltage was scanned from negative to positive values.

\section{Electrochemical impedance spectroscopy (EIS)}

EIS measurements were carried out on a ModuLab ${ }^{\circledR} \mathrm{XM}$ PhotoEchem photoelectrochemical measurement system from Solartron Analytical. The impedance was measured around the open-circuit potential of the cell at different light intensities (590 nm) in the frequency range $0.05 \mathrm{~Hz}$ to $400 \mathrm{kHz}$ using an amplitude of $10 \mathrm{mV}$. The impedance data were analysed using ZView $^{\circledR}$ software from Scribner Associates Inc.

\section{Results and discussion}

\section{DSC working-electrodes: commercial versus screen-printed NiO electrodes}

In previous investigations of p-type DCSs using in-house screenprinted FTO/NiO working electrodes sensitized with standard dye $\mathrm{P} 1$, optimal values of $J_{\mathrm{SC}}, V_{\mathrm{OC}}$ and $\eta$ (Table 2 ) were obtained using a $\left[\mathrm{Ni}(\mathrm{acac})_{2}\right]$ pretreatment and two-layers of NiO. ${ }^{10}$ The results are consistent with the benchmarking study of Gibson and coworkers. ${ }^{11}$ The electrolyte in these investigations was $\mathrm{I}_{3}{ }^{-} / \mathrm{I}^{-}$in AN. We also demonstrated that the performance of the cyclometallated dye $\left[\mathrm{Ru}(\mathrm{bpy})_{2}(\mathrm{H} 1)\right]$ exceeded that of $\mathrm{P} 1 .{ }^{10}$ In the development of our p-type DSC program, we purchased

Table 2 Performance data for duplicate DSCs containing dyes $\left[\mathrm{Ru}(\mathrm{bpy})_{2}(\mathrm{H} 1)\right]$ or P1. Measurements were made on the day of sealing the DSCs. Electrolyte $=\mathrm{I}_{3}^{-} / \mathrm{I}^{-}$in $\mathrm{MeCN}$

\begin{tabular}{|c|c|c|c|c|c|}
\hline Dye (DSC number) & FTO/NiO electrodes ${ }^{b}$ & $J_{\mathrm{SC}} / \mathrm{mA} \mathrm{cm}^{-2}$ & $V_{\mathrm{OC}} / \mathrm{mV}$ & $\mathrm{ff} / \%$ & $\eta / \%$ \\
\hline $\mathrm{P} 1(\text { cell } 1)^{a}$ & In-house & 1.84 & 88 & 35 & 0.057 \\
\hline $\mathrm{P} 1\left(\right.$ cell 2) ${ }^{a}$ & In-house & 1.96 & 82 & 32 & 0.051 \\
\hline P1 (cell 1) & Dyenamo & 2.76 & 92 & 33 & 0.085 \\
\hline P1 (cell 2) & Dyenamo & 2.42 & 97 & 34 & 0.079 \\
\hline$\left[\mathrm{Ru}(\mathrm{bpy})_{2}(\mathrm{H} \mathbf{1})\right]\left(\right.$ cell 1) ${ }^{a}$ & In-house & 3.38 & 95 & 36 & 0.116 \\
\hline$\left[\mathrm{Ru}(\mathrm{bpy})_{2}(\mathrm{H1})\right](\text { cell } 2)^{a}$ & In-house & 3.34 & 95 & 34 & 0.109 \\
\hline$\left[\mathrm{Ru}(\mathrm{bpy})_{2}(\mathrm{H1})\right]$ (cell 1) & Dyenamo & 4.06 & 95 & 36 & 0.139 \\
\hline$\left[\mathrm{Ru}(\mathrm{bpy})_{2}(\mathrm{H1})\right]($ cell 2$)$ & Dyenamo & 4.13 & 92 & 36 & 0.136 \\
\hline
\end{tabular}

${ }^{a}$ Data from ref. $10 .{ }^{b}$ Fabricated in-house (see Experimental section) or commercial from Dyenamo. 
commercial electrodes (Dyenamo) in order to compare the performance of DSCs sensitized with P1 or $\left[\mathrm{Ru}(\mathrm{bpy})_{2}(\mathrm{H} 1)\right]$ with commercial and in-house screen-printed working electrodes. The commercial electrodes were sintered (see Experimental section) before being immersed for $20 \mathrm{~h}$ in an AN solution of P1 or EtOH solution of $\left[\mathrm{Ru}(\mathrm{bpy})_{2}(\mathrm{H} 1)\right]$. DSCs were assembled as described in the Experimental section using an $\mathrm{I}_{3}{ }^{-} / \mathrm{I}^{-}$redox couple in AN. Values of $J_{\mathrm{SC}}, V_{\mathrm{OC}}$, the fill-factor (ff) and $\eta$ are given in Table 2, and the $J-V$ curves for the DSCs with commercial electrodes are shown in Fig. 2. The fill-factors for all DSCs are in the range $32-36 \%$. Compared to typical ff values of n-type DSCs, those for p-type cells are typically significantly lower, ${ }^{29}$ and the values in Table 2 compare well with the best reported for p-type DSCs. Both for the organic dye P1 and the cyclometallated ruthenium dye $\left[\mathrm{Ru}(\mathrm{bpy})_{2}(\mathrm{H1})\right]$, a change from in-house screenprinted to commercial working electrodes results in an increase in the photoconversion efficiency. For P1, this originates from higher $J_{\mathrm{SC}}$ and $V_{\mathrm{OC}}$, whereas for $\left[\mathrm{Ru}(\mathrm{bpy})_{2}(\mathrm{H} 1)\right]$, only $J_{\mathrm{SC}}$ is affected (Table 2). The values of $J_{\mathrm{SC}}=4.06$ and $4.13 \mathrm{~mA} \mathrm{~cm}^{-2}$ for the ruthenium dye are notably higher than for previously reported cyclometallated ruthenium dyes $\mathrm{s}^{5-8}$ and also higher than the 2.25 $\mathrm{mA} \mathrm{cm}{ }^{-2}$ reported for ruthenium diacetylide dyes. ${ }^{30}$ Values of $J_{\mathrm{SC}}$ $=4.06 \mathrm{~mA} \mathrm{~cm}{ }^{-2}, V_{\mathrm{OC}}=95 \mathrm{mV}$ and $\eta=0.139 \%$ for the better performing cell of the duplicate pair in Table 2 set a new record for state-of-the-art ${ }^{5}$ cyclometallated ruthenium dyes in p-type DSCs. Furthermore, the values of $J_{\mathrm{SC}}=4.06$ and $4.13 \mathrm{~mA} \mathrm{~cm}^{-2}$ obtained for the structurally unrefined $\left[\mathrm{Ru}(\mathrm{bpy})_{2}(\mathrm{H} 1)\right]$ compare well with the $4.16 \mathrm{~mA} \mathrm{~cm}{ }^{-2}$ obtained for the judiciously designed D-A-A organic dye (Scheme 2) reported recently by Zhu and coworkers in p-type DSCs; ${ }^{31}$ this dye was also used in conjunction with an $\mathrm{I}_{3}^{-} / \mathrm{I}^{-} / \mathrm{AN}$ electrolyte. In order to understand the enhancement on going from $\mathrm{P} 1$ to $\left[\mathrm{Ru}(\mathrm{bpy})_{2}(\mathrm{H} 1)\right]$, we turned to electrochemical impedance spectroscopy (EIS).

\section{Electrochemical impedance spectroscopy: [Ru(bpy $\left.)_{2}(\mathrm{H} 1)\right]$ versus $\mathrm{P} 1$}

EIS is a diagnostic tool for investigating electrochemical processes in a system and has been extensively used to study the internal kinetics of n-type DSCs. ${ }^{32-34}$ An AC voltage of varying

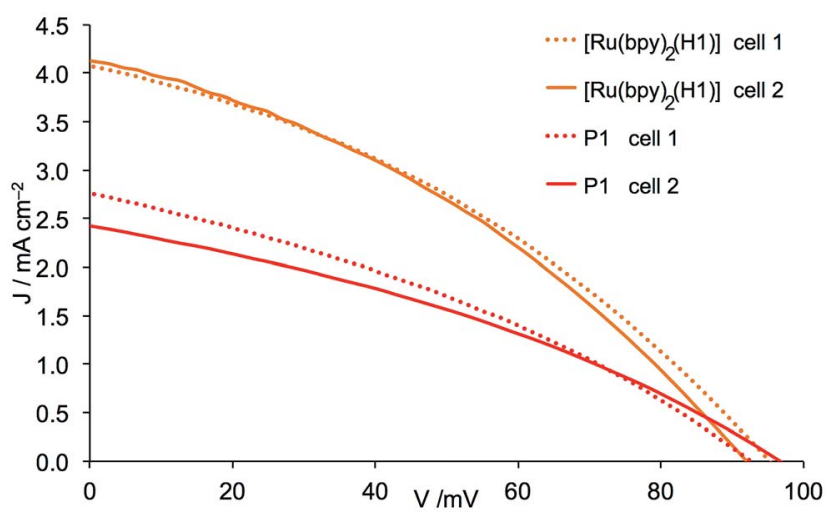

Fig. 2 J-V curves for duplicate DSCs containing commercial (Dyenamo) $\mathrm{FTO} / \mathrm{NiO}$ electrodes functionalized with dyes P1 and $\left[\mathrm{Ru}(\mathrm{bpy})_{2}(\mathrm{H} 1)\right]$ and an electrolyte comprising $\mathrm{I}_{3}^{-} / \mathrm{I}^{-}$in $\mathrm{MeCN}$.

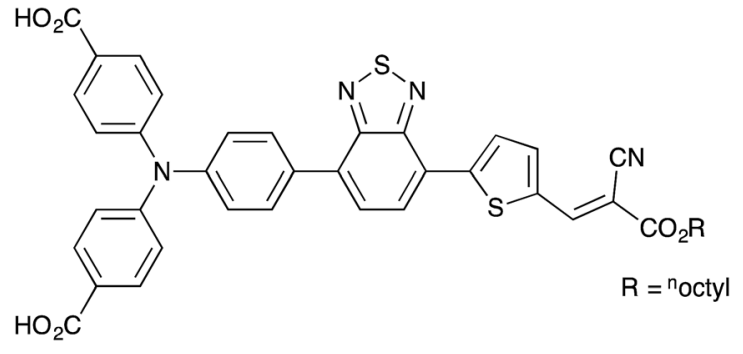

Scheme 2 The structure of the D-A-A organic dye with $J_{S C}=4.16$ $\mathrm{mA} \mathrm{cm}{ }^{-2}$ reported by Zhu and coworkers. ${ }^{31}$

frequency is applied to the DSC and the resulting current response is measured. Measurements have most often been carried out on n-type DSCs, and the results are normally depicted as three semi-circles in the form of a Nyquist plot. In the high frequency region, the first impedance contains only the series resistance that primarily arises from the electrical resistance between the semiconducting particles and the FTO glass; other factors such as cable resistance also contribute. This resistance is presented in the plot on the abscissa from zero to the start of the first semi-circle starts. This semi-circle represents the impedance given by charge transfer at the surface of the cathode, normally a Pt/electrolyte interface. The second semi-circle (intermediate frequency region) stems from the charge transfer impedance of electron recombination reactions at the semiconductor/ electrolyte interface. The third semi-circle, in the low frequency region, originates from the impedance of ion diffusion of the electrolyte. Depending on the magnitude of the recombination impedance and the ion diffusion impedance, this semi-circle may or may not be seen due to overlapping. It has been shown that the semi-circles obtained in EIS measurements of p-type DSCs originate from the same events as in n-type DSCs. ${ }^{35}$ Analysis of the EIS data allows multiple parameters including the recombination charge transfer resistance $\left(R_{\text {rec }}\right)$, active layer surface chemical capacitance $\left(C_{\mu}\right)$, transport resistance $\left(R_{\mathrm{t}}\right)$ and cathode charge transfer resistance $\left(R_{\mathrm{Pt}}\right)$ to be extracted. In the EIS investigations described below and later in the paper, the DSCs were constructed using commercial (Dyenamo) FTO/NiO working electrodes.

In the first part of the EIS study, a comparison was made of DSCs containing the dyes $\mathrm{P} 1$ and $\left[\mathrm{Ru}(\mathrm{bpy})_{2}(\mathrm{H} \mathbf{1})\right]$ in combination with an $\mathrm{I}_{3}{ }^{-} / \mathrm{I}^{-}$electrolyte in AN. Although the observed values of $V_{\mathrm{OC}}$ are similar for these two dyes (Table 2), $J_{\mathrm{SC}}$ is significantly lower for P1, reaching only $\sim 60-70 \%$ of the values obtained for DSCs with $\left[\mathrm{Ru}(\mathrm{bpy})_{2}(\mathrm{H} 1)\right]$ (Table 2 and Fig. 2). The EIS measurements reveal that DSCs with dye P1 exhibit a larger $R_{\text {rec }}$ and $R_{\mathrm{t}}$ (Table 3 and Fig. 3 ) than those with the ruthenium dye. This would be the expected result if fewer charge carriers, (in this case holes) are injected into the $\mathrm{NiO}$ which is consistent with the lower $J_{\mathrm{SC}}$. Consequently, fewer holes are available for back reactions from the semiconductor into the electrolyte and $R_{\mathrm{rec}}$ increases. The lower $C_{\mu}$ found for DSCs containing P1 versus $\left[\mathrm{Ru}(\mathrm{bpy})_{2}(\mathrm{H} \mathbf{1})\right]$ (Table 3) further supports this assumption. A higher $R_{\mathrm{t}}$ implies a larger density of trapped charge carriers in the semiconductor and, in the case of the p-type cell, means that 
the valence band is at more positive potential and as a consequence there is a larger hole transport resistance. The similar $V_{\text {OC }}$ values for the two dyes (Table 2 and Fig. 2), together with the fact that the same redox couple is used in the electrolyte for all DSCs, indicates that the band gap in the NiO is independent of the dye used in this study. Normally, a higher $R_{\text {rec }}$ is manifested in a higher $V_{\text {OC }}$, but this is not observed in this case. Therefore, it is more reasonable to assume that, compared to sensitization by the ruthenium dye, it is the lower number of holes generated when P1 is used that is the origin of the higher $R_{\text {rec }}$ and lower population of charge carriers.

\section{Effects of electrolyte solvent on DSC performance}

With the state-of-the-art performance of $\left[\mathrm{Ru}(\mathrm{bpy})_{2}(\mathrm{H} 1)\right]$ as a sensitizer in p-type DSCs established, we initiated investigations of the effects of changing the electrolyte. Improvement of photoconversion efficiency and long-term device stability were both critical goals. For the present study, we retain the $\mathrm{I}_{3}{ }^{-} / \mathrm{I}^{-}$ redox couple and focus on variation in the solvent. The low viscosity of AN (Table 1) contributes to its widespread use as a solvent, both for electrochemical studies and in DSCs. ${ }^{17}$ Although AN is commonly used in p-type DSCs (see the Introduction), its volatility is not compatible with long-term device stability. Increasing the length of the alkyl chain raises the boiling point, but also increases the viscosity (Table 1).

DSCs were assembled as described in the Experimental section using $\left[\mathrm{Ru}(\mathrm{bpy})_{2}(\mathrm{H} 1)\right]$ as sensitizer and an electrolyte

Table 3 EIS data obtained from measurements at a light intensity of 22 $\mathrm{mW} \mathrm{cm}^{-2}$ of $\mathrm{p}$-type DSCs containing $\mathrm{FTO} / \mathrm{NiO}$ (Dyenamo) working electrodes, dyes $\mathrm{P} 1$ or $\left[\mathrm{Ru}(\mathrm{bpy})_{2}(\mathrm{H} 1)\right]$ and $\mathrm{I}_{3}^{-} / \mathrm{I}^{-}$electrolyte in $\mathrm{MeCN}$

\begin{tabular}{|c|c|c|c|c|c|c|}
\hline Dye & $R_{\mathrm{t}} / \Omega$ & $R_{\mathrm{rec}} / \Omega$ & $C_{\mu} / \mu \mathrm{F}$ & $R_{\mathrm{Pt}} / \Omega$ & $C_{\mathrm{Pt}} / \mu \mathrm{F}$ & $\tau / \mathrm{ms}$ \\
\hline P1 (cell 1) & 55.9 & 159.1 & 1708.2 & 8.7 & 3.0 & 272 \\
\hline P1 (cell 2) & 77.7 & 190.9 & 1240.0 & 7.4 & 4.5 & 237 \\
\hline$\left[\mathrm{Ru}(\mathrm{bpy})_{2}(\mathrm{H} 1)\right]$ (cell 1) & 39.6 & 87.9 & 2107.5 & 7.3 & 3.4 & 185 \\
\hline$\left[\mathrm{Ru}(\mathrm{bpy})_{2}(\mathrm{H1})\right]($ cell 2$)$ & 40.4 & 80.1 & 1883.4 & 7.1 & 3.7 & 151 \\
\hline
\end{tabular}

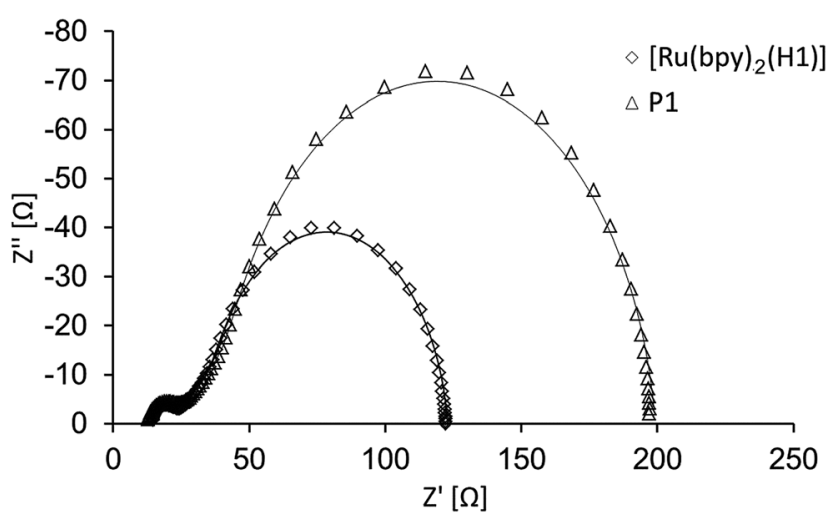

Fig. 3 Nyquist plots of two DSCs sensitized with $\left[\mathrm{Ru}(\mathrm{bpy})_{2}(\mathrm{H} 1)\right]$ and P1 respectively; the electrolyte is $\mathrm{I}_{3}^{-} / \mathrm{I}^{-}$in $\mathrm{AN}$. Both $R_{\text {rec }}$ and $R_{\mathrm{t}}$ are larger for $\mathrm{P} 1$ than the ruthenium dye. comprising $\mathrm{I}_{2}(0.1 \mathrm{M})$, LiI (1 M) in PN, VN, MPN or NMP. The working FTO/NiO electrodes were either commercial (Dyenamo) or were screen-printed using Solaronix NiO paste (see Experimental section). $J-V$ measurements were made using duplicate cells and the performance data are given in Tables 4 and 5; the data are compared to those for DSCs using AN. Fig. 4 and 5 depict the $J-V$ curves. For the discussion that follows, it is useful to recall the dependence of the overall DSC efficiency on $J_{\mathrm{SC}}$ and $V_{\text {OC }}$ (eqn (1), in which $P_{\text {IN }}$ is the total solar power incident on the cell, $100 \mathrm{~mW} \mathrm{~cm}^{-2}$ for air mass 1.5$)$.

$$
\eta=\frac{J_{\mathrm{SC}} V_{\mathrm{OC}} \mathrm{ff}}{P_{\mathrm{IN}}}
$$

A comparison of the data in Tables 4 and 5 and of the $J-V$ curves in Fig. 4 and 5 reveals the same trends irrespective of the source of the FTO/NiO electrodes. However, use of the commercial electrodes leads to higher values of $J_{\mathrm{SC}}$ in all solvents except NMP. For AN, PN, VN and MPN, the fill-factors are in the range $34-42 \%$. Values of $J_{\mathrm{SC}}$ are solvent dependent in the order AN $>$ PN $>$ MPN $>$ VN $>$ NMP, whilst $V_{\text {OC }}$ follows the trend $\mathrm{VN}>\mathrm{PN}>\mathrm{MPN}>\mathrm{AN}>\mathrm{NMP}$. With NMP, very low values of $J_{\mathrm{SC}}$ and $V_{\mathrm{OC}}$ both contribute to a poor overall $\eta$, and this solvent was therefore not further investigated. In the following discussion, we focus on the results obtained using commercial electrodes, noting that the trends are also valid for in-house screenprinted electrodes. Use of VN leads to impressive values of $V_{\mathrm{OC}}$ (139 and $141 \mathrm{mV}$ ) but these are at the expense of $J_{\mathrm{SC}}$ which, compared to the high values observed in AN, falls to around 1 $\mathrm{mA} \mathrm{cm}{ }^{-2}$, resulting in low overall photoconversion efficiencies of $\sim 0.06 \%$. Although using AN leads to a $V_{\mathrm{OC}}$ of only 92 or $95 \mathrm{mV}$, the remarkably good values of $J_{\mathrm{SC}}>4 \mathrm{~mA} \mathrm{~cm} \mathrm{~cm}^{-2}$ contribute to the best performing DSCs with $\eta=0.136$ and $0.139 \%$. A change from AN to the slightly less viscous PN results in a significant drop in $J_{\mathrm{SC}}$ countered by a gain in $V_{\mathrm{OC}}$ (Fig. 4). This is consistent with the increase in solvent donor number (Table 1). ${ }^{17}$ Overall, the DSCs retain a satisfactory overall efficiency of $0.117 \%$.

Although the results discussed above favour AN as the electrolyte solvent, the long-term stability of the DSCs remains an important factor. After the initial assessment of their performances, the DSCs were stored under ambient conditions for a month and then their $J-V$ characteristics were remeasured (Table 6 and Fig. 6, S4 $\dagger$ ). The fill-factors of all DSCs remain relatively high. One DSC containing AN aged badly with a drop in both $J_{\mathrm{SC}}$ and $V_{\mathrm{OC}}$, leading to a reduction in photoconversion efficiency from 0.139 to $0.088 \%$. Pleasingly, the cells containing PN show enhanced performance upon ageing with a gain in $J_{\mathrm{SC}}$ and no significant change in $V_{\text {OC }}$. This leads to an increase in $\eta$ from $0.117 \%$ to 0.154 and $0.146 \%$ for the two DSCs after 34 days, and this efficiency is essentially retained over the following 24 days. A ripening effect is also observed for the DSCs containing VN. Enhancement of DSC performance over time is a known phenomenon in n-type DSCs sensitized by some cop$\operatorname{per}(\mathrm{I})^{36}$ or ruthenium(II) dyes and appears to be associated with the formation of dye-aggregates which ultimately reorganize on the surface over periods of days. ${ }^{37-39}$ DSCs containing MPN 
Table 4 Performance data for duplicate DSCs containing $\left[\mathrm{Ru}(\mathrm{bpy})_{2}(\mathrm{H} 1)\right]$ and $\mathrm{I}_{3}^{-} / \mathrm{I}^{-}$redox couple. Measurements were made on the day of sealing the DSCs. The FTO/NiO electrodes were purchased from Dyenamo

\begin{tabular}{|c|c|c|c|c|c|}
\hline Solvent in electrolyte ${ }^{a}$ & DSC number & $J_{\mathrm{SC}} / \mathrm{mA} \mathrm{cm}^{-2}$ & $V_{\mathrm{OC}} / \mathrm{mV}$ & $\mathrm{ff} / \%$ & $\eta / \%$ \\
\hline $\mathrm{AN}^{b}$ & Cell 1 & 4.06 & 95 & 36 & 0.139 \\
\hline $\mathrm{AN}^{b}$ & Cell 2 & 4.13 & 92 & 36 & 0.136 \\
\hline PN & Cell 2 & 2.51 & 119 & 39 & 0.117 \\
\hline $\mathrm{VN}$ & Cell 1 & 1.04 & 139 & 42 & 0.060 \\
\hline $\mathrm{VN}$ & Cell 2 & 0.98 & 141 & 41 & 0.057 \\
\hline NMP & Cell 1 & 0.41 & 78 & 33 & 0.010 \\
\hline NMP & Cell 2 & 0.40 & 79 & 33 & 0.011 \\
\hline
\end{tabular}

${ }^{a}$ Acetonitrile (AN); propionitrile (PN), valeronitrile (VN), 3-methoxypropionitrile (MPN); $N$-methylpyrrolidone (NMP). ${ }^{b}$ Data from Table 2.

Table 5 Performance data for duplicate DSCs containing $\left[\mathrm{Ru}(\mathrm{bpy})_{2}(\mathrm{H} 1)\right]$ and $\mathrm{I}_{3}^{-} / \mathrm{I}^{-}$redox couple. Measurements were made on the day of sealing the DSCs. The FTO/NiO electrodes were purchased screen-printed using Solaronix NiO paste ${ }^{a}$

\begin{tabular}{|c|c|c|c|c|c|}
\hline Solvent in electrolyte & DSC number & $J_{\mathrm{SC}} / \mathrm{mA} \mathrm{cm}^{-2}$ & $V_{\mathrm{OC}} / \mathrm{mV}$ & $\mathrm{ff} / \%$ & $\eta / \%$ \\
\hline $\mathrm{AN}^{b}$ & Cell 2 & 3.34 & 95 & 34 & 0.109 \\
\hline PN & Cell 2 & 2.16 & 118 & 39 & 0.100 \\
\hline $\mathrm{VN}$ & Cell 1 & 0.64 & 149 & 36 & 0.033 \\
\hline VN & Cell 2 & 0.64 & 148 & 34 & 0.031 \\
\hline NMP & Cell 1 & 0.41 & 65 & 30 & 0.008 \\
\hline NMP & Cell 2 & 0.44 & 70 & 31 & 0.009 \\
\hline
\end{tabular}

${ }^{a}$ Data from Table $1 .^{b}$ Data from ref. 10.

retain their original performances over the first 34 days and perform less well thereafter (Table 6).

\section{Electrochemical impedance spectroscopy: solvent effects}

As discussed above, the efficiencies of DSCs sensitized with $\left[\mathrm{Ru}(\mathrm{bpy})_{2}(\mathrm{H} 1)\right]$ are significantly influenced by the choice of solvent in the electrolyte. The $V_{\mathrm{OC}}$ is highest for $\mathrm{VN}$ and $\mathrm{PN}$, but

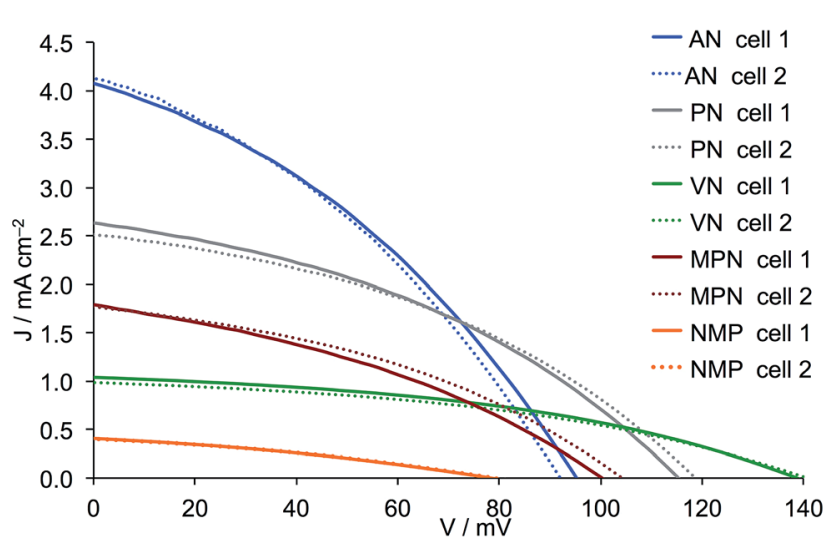

Fig. 4 J-V curves for duplicate DSCs containing commercial (Dyenamo) $\mathrm{FTO} / \mathrm{NiO}$ electrodes functionalized with $\left[\mathrm{Ru}(\mathrm{bpy})_{2}(\mathrm{H} 1)\right]$ and electrolytes comprising $\mathrm{I}_{3}^{-} / \mathrm{I}^{-}$in different solvents. See footnote to Table 4 for solvent abbreviations. the main factor influencing the overall DSC efficiency is $J_{\mathrm{SC}}$. For the EIS study, DSCs using commercial FTO/NiO electrodes were used, and we focused only on the solvents AN, PN and MPN, all of which have similar donor numbers (Table 1). This effectively removes one variable and allows us observe more clearly the effects of the solvent viscosity which follows the order $\mathrm{AN}<\mathrm{PN}<$

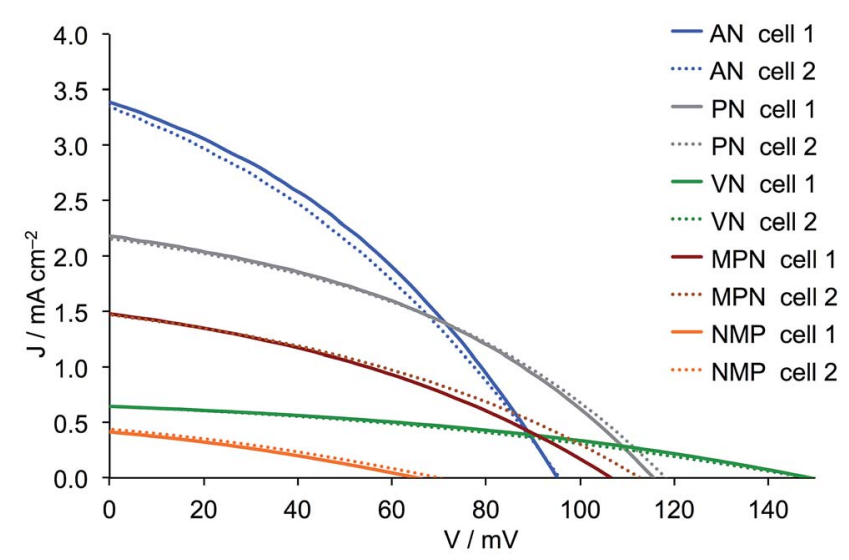

Fig. $5 \mathrm{~J}-\mathrm{V}$ curves for duplicate DSCs containing $\mathrm{FTO} / \mathrm{NiO}$ electrodes screen-printed using Solaronix $\mathrm{NiO}$ paste and functionalized with $\left[\mathrm{Ru}(\mathrm{bpy})_{2}(\mathrm{H} 1)\right]$. The electrolytes comprised $\mathrm{I}_{3}^{-} / \mathrm{I}^{-}$in different solvents. See footnote to Table 4 for solvent abbreviations. 
Table 6 Long term performance data for duplicate DSCs containing $\left[\mathrm{Ru}(\mathrm{bpy})_{2}(\mathrm{H} 1)\right]$ and $\mathrm{I}_{3}^{-} / \mathrm{I}^{-}$redox couple. Commercial FTO/NiO electrodes (Dyenamo) were used

\begin{tabular}{llllll}
\hline Solvent in electrolyte & $\begin{array}{l}\text { DSC } \\
\text { number }\end{array}$ & $\begin{array}{l}J_{\mathrm{SC}} / \\
\mathrm{mA} \mathrm{cm}^{-2}\end{array}$ & $\begin{array}{l}V_{\mathrm{OC}} / \\
\mathrm{mV}\end{array}$ & $\begin{array}{l} \\
\mathrm{ff} / \%\end{array}$ & $\eta / \%$ \\
\hline On day 33 or 34 (see Fig. 6) & & & & \\
AN & Cell 1 & 3.17 & 89 & 34 & 0.096 \\
AN & Cell 2 & 4.15 & 82 & 35 & 0.121 \\
PN & Cell 1 & 3.17 & 119 & 41 & 0.154 \\
PN & Cell 2 & 2.99 & 119 & 41 & 0.146 \\
VN & Cell 1 & 1.18 & 148 & 44 & 0.077 \\
VN & Cell 2 & 1.14 & 146 & 43 & 0.071 \\
MPN & Cell 1 & 1.69 & 91 & 38 & 0.058 \\
MPN & Cell 2 & 1.61 & 97 & 40 & 0.063 \\
& & & & & \\
On day 57 or 58 (see Fig. S4) & & & & \\
AN & Cell 1 & 3.00 & 86 & 34 & 0.088 \\
AN & Cell 2 & 3.81 & 83 & 32 & 0.102 \\
PN & Cell 1 & 3.04 & 122 & 40 & 0.148 \\
PN & Cell 2 & 2.96 & 118 & 41 & 0.142 \\
VN & Cell 1 & 1.25 & 153 & 41 & 0.079 \\
VN & Cell 2 & 1.06 & 155 & 39 & 0.065 \\
MPN & Cell 1 & 1.37 & 89 & 29 & 0.035 \\
MPN & Cell 2 & 1.38 & 101 & 31 & 0.043 \\
& & & & & \\
\hline
\end{tabular}

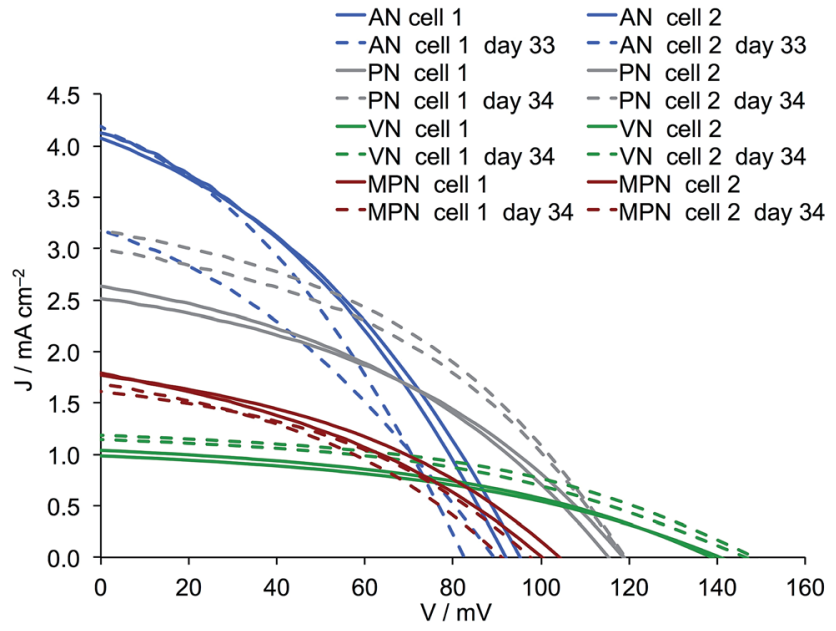

Fig. 6 J-V curves for duplicate DSCs containing commercial FTO/ $\mathrm{NiO}$ electrodes functionalized with $\left[\mathrm{Ru}(\mathrm{bpy})_{2}(\mathrm{H} 1)\right]$ and electrolytes comprising $\mathrm{I}_{3}^{-} / \mathrm{I}^{-}$in AN, PN, VN or MPN. Measurements were made on day 0 and 33 or 34 days later.

MPN which is the inverse of the trend in $J_{\mathrm{SC}}$ (Fig. 4). A high viscosity decreases the diffusion coefficient for the redox mediators in the electrolyte ${ }^{40}$ and, following the reasoning discussed earlier, should lead to an increase in $R_{\text {rec }}$. The results of the EIS studies on duplicate cells (the same DSCs as used for the $J-V$ measurements) are given in Table 7, and Nyquist plots for the better performing of each pairs of DSCs with commercial electrodes (see Table 4) are shown in Fig. 7.

As the electrolyte viscosity increases, the ion diffusion decreases and the current density is lowered. This results in an increase in $R_{\text {rec }}$, since fewer charge carriers are available for back reaction. Both these changes can be observed in Tables 4 and 7. However, if Table 7 is studied, it can be seen that $C_{\mu}$ is highest for the MPN cells, meaning that the total density of charge carriers in the semiconductor is high. ${ }^{35}$ This, together with the highest $R_{\text {rec }}$ results in a long charge carrier lifetime, or in other words, an efficient hole injection (Table 7). The hole transport resistance, $R_{\mathrm{t}}$, is however lowest for the $\mathrm{AN}$ electrolyte while intermediate for the MPN electrolyte, and suggest that the cells with MPN have a higher density of charge carrier trap states. This agrees with the decreased $J_{\mathrm{SC}}$ for the MPN cells. Furthermore, the high back electrode charge transfer resistance, $R_{\mathrm{Pt}}$, is more than twice as large for the MPN cell

Table 7 EIS data obtained from measurements at a light intensity of 22 $\mathrm{mW} \mathrm{cm}^{-2}$ of $\mathrm{p}$-type DSCs containing $\mathrm{FTO} / \mathrm{NiO}$ (Dyenamo) working electrodes, the dye $\left[\mathrm{Ru}(\mathrm{bpy})_{2}(\mathrm{H} 1)\right]$ and $\mathrm{I}_{3}^{-} / \mathrm{I}^{-}$electrolyte in different solvents

\begin{tabular}{lrrrrrr}
$\begin{array}{l}\text { Solvent } \\
\text { (DSC number) }\end{array}$ & \multicolumn{1}{c}{$R_{\mathrm{t}} / \Omega$} & \multicolumn{1}{c}{$R_{\mathrm{rec}} / \Omega$} & $C_{\mu} / \mu \mathrm{F}$ & $R_{\mathrm{Pt}} / \Omega$ & $C_{\mathrm{Pt}} / \mu \mathrm{F}$ & $\tau / \mathrm{ms}$ \\
\hline AN (cell 1) & 39.6 & 87.9 & 2107.5 & 7.3 & 3.4 & 185 \\
AN (cell 2) & 40.4 & 80.1 & 1883.4 & 7.1 & 3.7 & 151 \\
PN (cell 1) & 96.4 & 146.3 & 1685.4 & 8.2 & 4.0 & 247 \\
PN (cell 2) & 109.0 & 129.3 & 1451.7 & 12.9 & 3.7 & 188 \\
MPN (cell 1) & 70.4 & 332.2 & 2170.3 & 20.4 & 4.0 & 721 \\
MPN (cell 2) & 56.6 & 248.6 & 2160.5 & 18.4 & 3.8 & 537
\end{tabular}
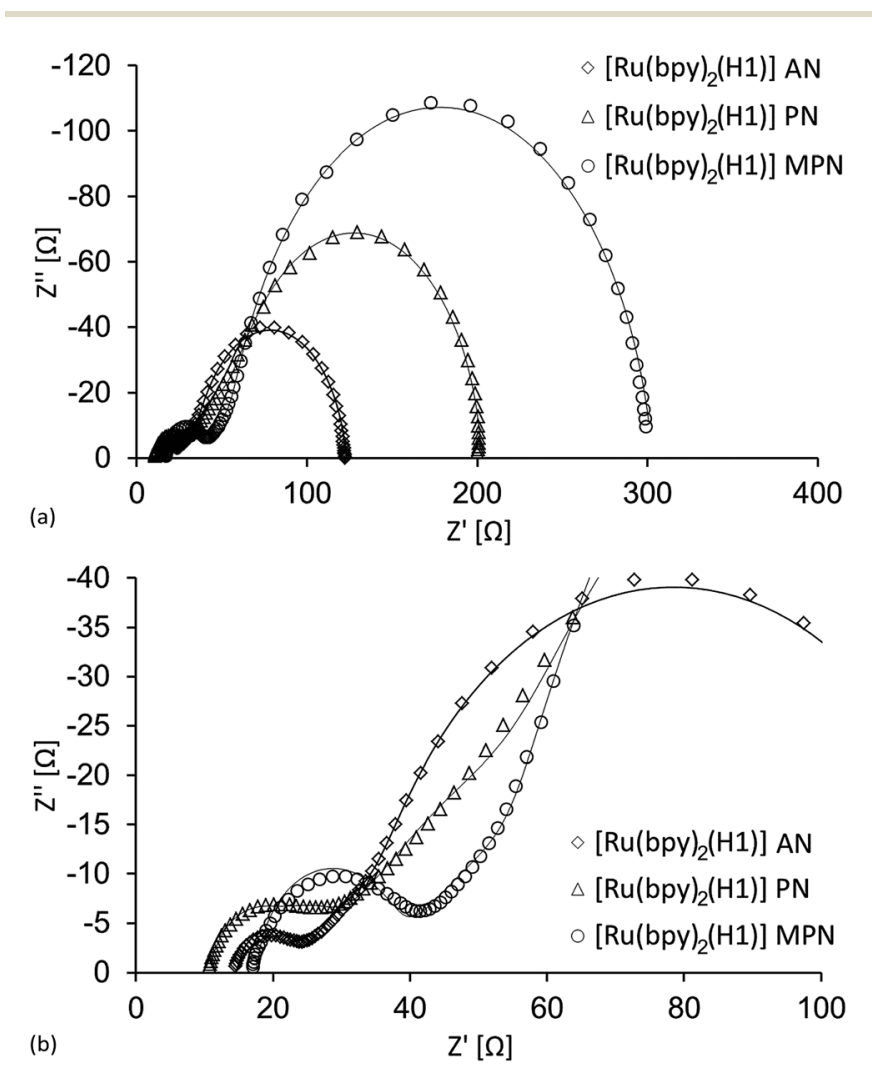

Fig. 7 (a) Nyquist plots of three cells sensitized with the dye $\left[\mathrm{Ru}(\mathrm{bpy})_{2}(\mathrm{H} 1)\right]$ with different electrolyte solvents. (b) Expansion of the intermediate/high frequency region. 
compared to the AN one, and the performance deteriorates even further.

The PN cells possess the highest $V_{\text {OC }}$, which is indicative of a larger band gap. Moreover, they have the largest values of $R_{\mathrm{t}}$ (Fig. 7b). $R_{\mathrm{t}}$ is directly affected by the valence band level, indicating that the latter is shifted towards a more positive potential for these cells. As mentioned above, a high $R_{\mathrm{t}}$ is suggestive of a high density of charge carrier trap states, and this together with the low chemical capacitance give rise to the relatively moderate performance of the PN cells.

\section{Mixed solvents}

In n-type DSCs, the use of mixed solvents is routine. ${ }^{17}$ These are commonly based on AN with a higher boiling organic nitrile, often VN or MPN, as cosolvent. Screening of AN, PN, VN and MPN for use with the $\mathrm{I}_{3}{ }^{-} / \mathrm{I}^{-}$redox couple and the dye $\left[\mathrm{Ru}(\mathrm{bpy})_{2}(\mathrm{H} 1)\right]$ in p-type DSCs revealed benefits and disadvantages of each solvent. For optimal performance on the day the DSCs are made, AN is the superior solvent. PN or MPN lead to greater device stability, but at the expense of performance compared to AN. The highest values of $V_{\mathrm{OC}}$ are obtained with VN.

A series of electrolytes was prepared using $\mathrm{I}_{2}(0.1 \mathrm{M}), \operatorname{LiI}(1 \mathrm{M})$ in mixed solvents as specified in Table 8. DSCs were assembled as described earlier and the device performances are

Table 8 Performance data for duplicate DSCs containing $\left[R u(b p y)_{2}\right.$ $(\mathrm{H} 1)]$ and $\mathrm{I}_{3}^{-} / \mathrm{I}^{-}$redox couple in mixed solvents, using commercial FTO/NiO electrodes (Dyenamo). Data for pure AN, PN, VN and MPN are repeated from Table 4 for convenience

\begin{tabular}{|c|c|c|c|c|c|}
\hline $\begin{array}{l}\text { Solvent in electrolyte } \\
\text { (ratio by volume) }\end{array}$ & $\begin{array}{l}\text { DSC } \\
\text { number }\end{array}$ & $\begin{array}{l}J_{\mathrm{SC}} / \\
\mathrm{mA} \mathrm{cm}\end{array}$ & $V_{\mathrm{OC}} / \mathrm{mV}$ & $\mathrm{ff} / \%$ & $\eta / \%$ \\
\hline $\mathrm{AN}$ & Cell 1 & 4.06 & 95 & 36 & 0.139 \\
\hline $\mathrm{AN}$ & Cell 2 & 4.13 & 92 & 36 & 0.136 \\
\hline AN : PN $3: 1$ & Cell 1 & 3.64 & 99 & 38 & 0.138 \\
\hline AN : PN $3: 1$ & Cell 2 & 3.60 & 100 & 38 & 0.137 \\
\hline AN : PN $1: 1$ & Cell 1 & 3.34 & 115 & 37 & 0.142 \\
\hline AN : PN $1: 1$ & Cell 2 & 3.36 & 112 & 37 & 0.140 \\
\hline AN : PN $1: 3$ & Cell 1 & 2.79 & 106 & 38 & 0.111 \\
\hline $\mathrm{AN}: \mathrm{PN} 1: 3$ & Cell 2 & 2.86 & 105 & 38 & 0.113 \\
\hline PN & Cell 1 & 2.63 & 115 & 39 & 0.117 \\
\hline PN & Cell 2 & 2.51 & 119 & 39 & 0.117 \\
\hline AN : VN $3: 1$ & Cell 1 & 3.14 & 115 & 39 & 0.141 \\
\hline AN $:$ VN $3: 1$ & Cell 2 & 3.27 & 115 & 40 & 0.148 \\
\hline $\mathrm{AN}: \mathrm{VN} 1: 1$ & Cell 1 & 2.43 & 119 & 40 & 0.115 \\
\hline AN : VN $1: 1$ & Cell 2 & 2.38 & 121 & 40 & 0.115 \\
\hline $\mathrm{AN}: \mathrm{VN} 1: 3$ & Cell 1 & 1.58 & 133 & 42 & 0.087 \\
\hline AN : VN $1: 3$ & Cell 2 & 1.58 & 133 & 39 & 0.081 \\
\hline $\mathrm{VN}$ & Cell 1 & 1.04 & 139 & 42 & 0.060 \\
\hline $\mathrm{VN}$ & Cell 2 & 0.98 & 141 & 41 & 0.057 \\
\hline AN : MPN $3: 1$ & Cell 1 & 2.97 & 102 & 37 & 0.112 \\
\hline AN : MPN $3: 1$ & Cell 2 & 2.90 & 97 & 39 & 0.109 \\
\hline AN : MPN $1: 1$ & Cell 1 & 2.74 & 111 & 38 & 0.117 \\
\hline AN : MPN $1: 1$ & Cell 2 & 2.85 & 104 & 38 & 0.112 \\
\hline AN : MPN $1: 3$ & Cell 1 & 2.25 & 112 & 39 & 0.097 \\
\hline AN $:$ MPN $1: 3$ & Cell 2 & 2.21 & 106 & 38 & 0.089 \\
\hline MPN & Cell 1 & 1.79 & 100 & 36 & 0.064 \\
\hline MPN & Cell 2 & 1.77 & 104 & 38 & 0.070 \\
\hline
\end{tabular}

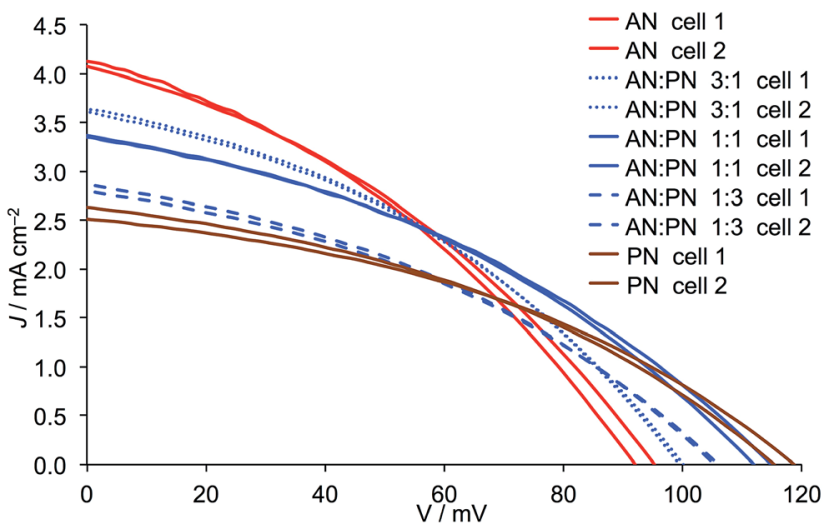

Fig. $8 \mathrm{~J}-V$ curves for duplicate DSCs containing Dyenamo FTO/NiO electrodes functionalized with $\left[\mathrm{Ru}(\mathrm{bpy})_{2}(\mathrm{H} 1)\right]$ and electrolytes comprising $\mathrm{I}_{3}^{-} / \mathrm{I}^{-}$in $\mathrm{AN}$, PN or $\mathrm{AN}$ : PN mixed solvent. Ratios of solvents are by volume.

summarized in Table 8 (Dyenamo FTO/NiO working electrodes) and Table $\mathrm{S} 1 \dagger$ (in-house screen-printed electrodes). Fig. 8-10 and $\mathrm{S} 1-\mathrm{S} 3 \dagger$ show the $J-V$ curves. Use of duplicate DSCs, and a comparison of the data for the differently sourced working electrodes confirm the general trends discussed below. For the discussion, we focus only on the data in Table 8 and Fig. 8-10.

The addition of either PN, VN or MPN to AN leads to a reduction in $J_{\mathrm{SC}}$ and this is most pronounced for $\mathrm{VN}$ and least for PN (Fig. 9 versus Fig. 8). Adding either PN or VN leads to an incremental increase in $V_{\mathrm{OC}}$ as the amount of second solvent increases. These trends are consistent with the general observation (albeit it in n-type DSCs) that an increase in donor number (Table 1) results in lower $J_{\mathrm{SC}}$ but improved $V_{\mathrm{OC}} \cdot{ }^{17}$ Note that for AN/MPN, the optimal $V_{\mathrm{OC}}$ is reached for $1: 1$ or $1: 3$ mixtures rather than for pure MPN (Fig. 10). For PN, the opposing trends in $J_{\mathrm{SC}}$ and $V_{\mathrm{OC}}$ along the solvent series from pure AN to a $3: 1$ and then to a $1: 1 \mathrm{AN}: \mathrm{PN}$ mixture, led to little change in the overall DSC efficiency (Table 8). For both VN and MPN, the general trend is for a decrease in photoconversion

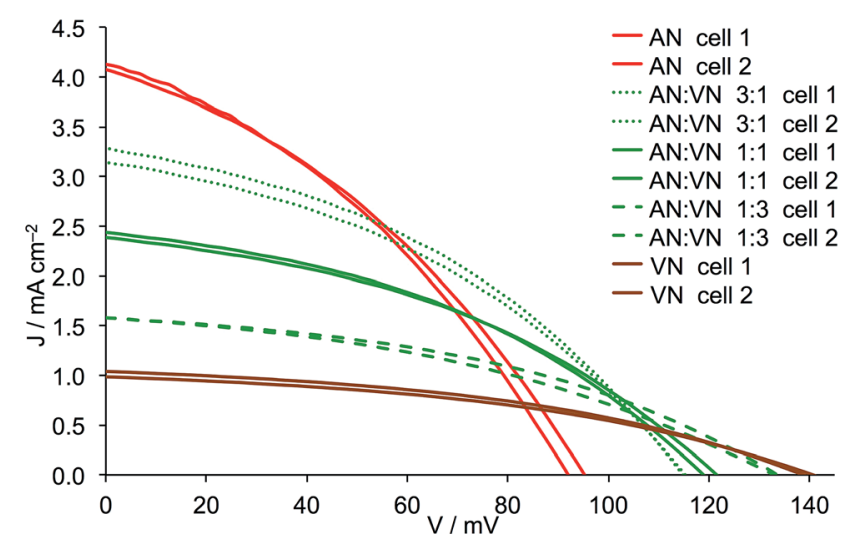

Fig. $9 \mathrm{~J}-\mathrm{V}$ curves for duplicate DSCs containing Dyenamo FTO/NiO electrodes functionalized with $\left[\mathrm{Ru}(\mathrm{bpy})_{2}(\mathrm{H} 1)\right]$ and electrolytes comprising $\mathrm{I}_{3}^{-} / \mathrm{I}^{-}$in $\mathrm{AN}, \mathrm{VN}$ or $\mathrm{AN}$ : $\mathrm{VN}$ mixed solvent. Ratios of solvents are by volume. 


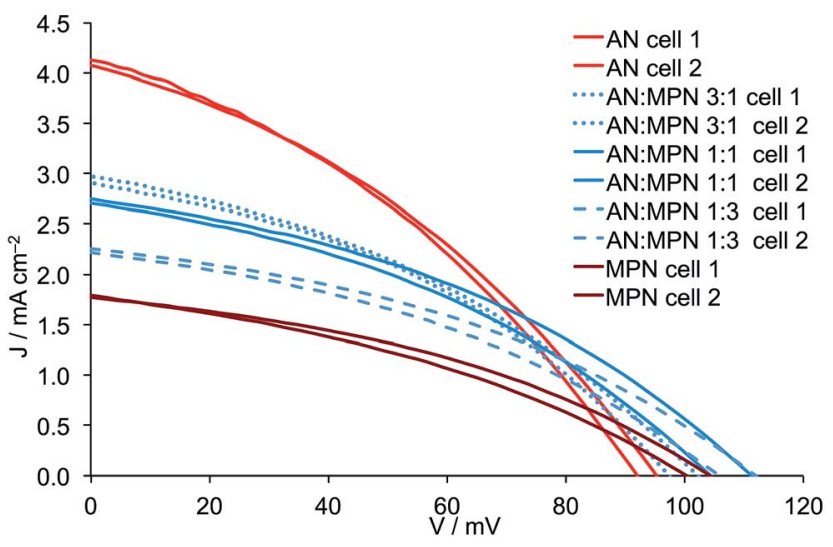

Fig. $10 \mathrm{~J}-\mathrm{V}$ curves for duplicate DSCs containing Dyenamo FTO/NiO electrodes functionalized with $\left[\mathrm{Ru}(\mathrm{bpy})_{2}(\mathrm{H} 1)\right]$ and electrolytes comprising $\mathrm{I}_{3}^{-} / \mathrm{I}^{-}$in AN, MPN or AN : MPN mixed solvent. Ratios of solvents are by volume.

efficiency as these solvents are mixed in increasing amounts with AN. Thus, the benefits of the higher $V_{\mathrm{OC}}$ observed when solvents with a higher donor number are introduced into the electrolyte are only carried through to the overall efficiency when the second solvent is PN, the drop in $J_{\mathrm{SC}}$ being too large in the cases of VN and MPN. The conclusion of this part of the investigation is that the optimal mixed solvent of those studied is an AN:PN mixture with volume ratios of $3: 1$ or $1: 1$ (Table 8).

Finally, we consider the effects of ageing DSCs with the AN : PN mixtures. Table 9 gives the performance data for four cells in Table 8 in which the AN : PN volume ratios are $3: 1$ or $1: 1$. After 39 days, values of $J_{\mathrm{SC}}$ increase while $V_{\mathrm{OC}}$ remains stable ( $3: 1$ ratio) or falls $(1: 1$ ratio) (Fig. 11). The fill-factors are little affected and the overall result is that $\eta$ increases (Table 8 versus Table 9) with the best photoconversion efficiency being $0.162 \%$. The current densities of 3.86 and $3.89 \mathrm{~mA} \mathrm{~cm} \mathrm{~cm}^{-2}$ for these DSCs (Table 9) approach those recorded for DSCs on the day of cell fabrication in which the solvent is pure AN (Table 2). Further ageing results in a decrease in performance (Table 9 and Fig. 11) and a contributing factor is the lower fill-factors (31-

Table 9 Long term performance data for duplicate DSCs containing $\left[\mathrm{Ru}(\mathrm{bpy})_{2}(\mathrm{H} 1)\right]$ and $\mathrm{I}_{3}^{-} / \mathrm{I}^{-}$redox couple with $\mathrm{AN}$, and $\mathrm{AN}$ : PN solvents. Commercial FTO/NiO electrodes (Dyenamo) were used

\begin{tabular}{llllll}
\hline $\begin{array}{l}\text { Solvent in } \\
\text { electrolyte }\end{array}$ & $\begin{array}{l}\text { DSC } \\
\text { number }\end{array}$ & $J_{\mathrm{SC}} / \mathrm{mA} \mathrm{cm}^{-2}$ & $V_{\mathrm{OC}} / \mathrm{mV}$ & $\mathrm{ff} / \%$ & $\eta / \%$ \\
\hline On day 39 & & & & & \\
AN : PN 3 : 1 & Cell 1 & 3.86 & 97 & 38 & 0.142 \\
AN : PN 3 : 1 & Cell 2 & 3.88 & 100 & 41 & 0.158 \\
AN : PN 1:1 & Cell 1 & 3.86 & 107 & 39 & 0.162 \\
AN : PN 1: 1 & Cell 2 & 3.89 & 105 & 40 & 0.162 \\
& & & & & \\
On day 63 & & & & & \\
AN : PN 3 : 1 & Cell 1 & 3.52 & 97 & 32 & 0.111 \\
AN : PN 3:1 & Cell 2 & 3.62 & 99 & 38 & 0.138 \\
AN : PN 1 : 1 & Cell 1 & 3.49 & 108 & 31 & 0.118 \\
AN : PN 1 : 1 & Cell 2 & 3.59 & 111 & 35 & 0.139
\end{tabular}

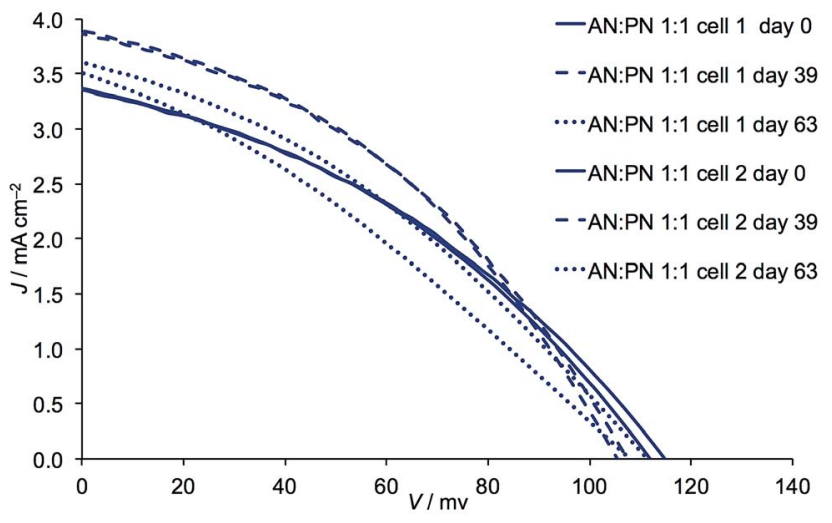

Fig. 11 Effects of ageing: J-V curves for duplicate DSCs containing Dyenamo $\mathrm{FTO} / \mathrm{NiO}$ electrodes functionalized with $\left[\mathrm{Ru}(\mathrm{bpy})_{2}(\mathrm{H} 1)\right]$ and electrolytes comprising $\mathrm{I}_{3}^{-} \mathrm{I}^{-}$in $\mathrm{AN}$ : PN mixed solvent $1: 1$ by volume.

$38 \%$ ), suggesting deterioration of the cell integrity. Nonetheless, the mixed solvent leads to noticeably better long-term stability than for the DSCs containing only AN (Table 9 versus Table 6).

\section{Conclusions}

We have investigated the effect of electrolyte solvent on the performances of p-type dye DSCs sensitized with the structurally simple cyclometallated ruthenium dye $\left[\mathrm{Ru}(\mathrm{bpy})_{2}(\mathrm{H} \mathbf{1})\right]$ adsorbed on $\mathrm{FTO} / \mathrm{NiO}$ photocathodes and with an $\mathrm{I}_{3}{ }^{-} / \mathrm{I}^{-}$redox couple. Using $\mathrm{AN}$ as solvent in the electrolyte and with commercial FTO/NiO electrodes, values of $J_{\mathrm{sC}}=4.06 \mathrm{~mA} \mathrm{~cm}^{-2}$, $V_{\mathrm{OC}}=95 \mathrm{mV}$ and $\eta=0.139 \%$ are achieved which are the highest reported for cyclometallated ruthenium dyes in p-type DSCs. $J_{\mathrm{SC}}$ values for $\left[\mathrm{Ru}(\mathrm{bpy})_{2}(\mathrm{H} 1)\right]$ are higher than those observed for the standard dye P1, and EIS shows that DSCs with [Ru(bpy $\left.)_{2}(\mathrm{H} 1)\right]$ exhibit a both a lower transport resistance $\left(R_{\mathrm{t}}\right)$ and recombination resistance $\left(R_{\mathrm{rec}}\right)$ than DSCs with P1.

Screening of AN, PN, VN and MPN for use with the $\mathrm{I}_{3}{ }^{-} / \mathrm{I}^{-}$ redox shuttle and sensitizer $\left[\mathrm{Ru}(\mathrm{bpy})_{2}(\mathrm{H} 1)\right]$ leads to the conclusion that AN gives the highest $J_{\mathrm{SC}}$ and highest $\eta$, but poorest long-term stability. DSCs with the less volatile and more viscous PN show a ripening effect over the first 33 days with a gain in $J_{\mathrm{SC}}$. Although exceptional values of $V_{\mathrm{OC}}$ are obtained with $\mathrm{VN}$, this is at the expense of $J_{\mathrm{SC}}$ which decreases dramatically compared to values with AN as solvent. Values of $J_{\mathrm{SC}}$ depend upon solvent in the order AN $>$ PN $>$ MPN $>$ VN $>$ NMP, whilst for $V_{\mathrm{OC}}$ the trend is $\mathrm{VN}>\mathrm{PN}>\mathrm{MPN}>\mathrm{AN}>\mathrm{NMP}$. As the electrolyte viscosity increases, the ion diffusion is reduced and, therefore, current density decreases. This is consistent with the EIS measurements which show an increase in $R_{\text {rec }}$ due to fewer charge carriers being available for back reaction. However, it was also shown that the variation in $R_{\text {rec }}$ does not completely account for the differences in DSC performance with solvent. The values of $R_{\mathrm{t}}$ and $R_{\mathrm{P}}$ play a crucial role where $R_{\mathrm{t}}$ is highest for $\mathrm{PN}$, whilst $R_{\mathrm{Pt}}$ is highest for the MPN cells.

Based upon the analysis of the benefits and disadvantages of the different solvents, electrolytes with mixed solvents were 
investigated. The addition of $\mathrm{PN}, \mathrm{VN}$ or MPN to AN leads to lower $J_{\mathrm{SC}}$ values, the change being most noticeable for $\mathrm{VN}$ and least so for PN. The optimal solvent is an AN : PN mixture with volume ratios of $3: 1$ or $1: 1$; this mixed solvent provides the DSCs with an enhanced long-term stability with respect to cells containing only AN and, significantly, this is achieved with only a small decrease in overall photoconversion efficiency.

\section{Acknowledgements}

We thank the Swiss National Science Foundation (Grant number CR22I2_156236) and the University of Basel for financial support. We thank (Cedric Wobill, ${ }^{\mathbf{1 0}}$ Department of Chemistry, University of Basel) for providing $\left[\mathrm{Ru}(\mathrm{bpy})_{2}(\mathrm{H} 1)\right]$. Professor Ernst Meyer and Dr Thilo Glatzel (Department of Physics, University of Basel) for helpful discussions.

\section{Notes and references}

1 K. C. D. Robson, P. G. Bomben and C. P. Berlinguette, Dalton Trans., 2012, 41, 7814 and references therein.

2 P. G. Bomben, K. C. D. Robson, B. D. Koivisto and C. P. Berlinguette, Coord. Chem. Rev., 2012, 256, 1438 and references therein.

3 A. Colombo, C. Dragonetti, A. Valore, C. Coluccini, N. Manfredi and A. Abbotto, Polyhedron, 2014, 82, 50 and references therein.

4 P. G. Bomben, K. C. D. Robson, P. A. Sedach and C. P. Berlinguette, Inorg. Chem., 2009, 48, 9631.

5 M. He, Z. Ji, Z. Huang and Y. Wu, J. Phys. Chem. C, 2014, 118, 16518

6 Z. Ji, G. Natu and Y. Wu, ACS Appl. Mater. Interfaces, 2013, 5, 8641.

7 Z. Ji, G. Natu, Z. Huang, O. Kokhan, X. Zhang and Y. Wu, J. Phys. Chem. C, 2012, 116, 16854.

8 Z. Ji and Y. Wu, J. Phys. Chem. C, 2013, 117, 18315.

9 C. J. Wood, K. C. D. Robson, P. I. P. Elliott, C. P. Berlinguette and E. A. Gibson, $R S C A d v .$, 2014, 4, 5782.

10 F. Brunner, N. Marinakis, C. Wobill, M. Willgert, C. D. Ertl, T. Kosmalski, M. Neuburger, B. Bozic-Weber, T. Glatzel, E. C. Constable and C. E. Housecroft, J. Mater. Chem. C, 2016, 4, 9823.

11 C. J. Wood, G. H. Summers, C. A. Clark, N. Kaeffer, M. Braeutigam, L. R. Carbone, L. D'Amario, K. Fan, Y. Farré, S. Narbey, F. Oswald, L. A. Stevens, C. D. J. Parmenter, M. W. Fay, A. La Torre, C. E. Snape, B. Dietzek, D. Dini, L. Hammarström, Y. Pellegrin, F. Odobel, L. Sun, V. Artero and E. A. Gibson, Phys. Chem. Chem. Phys., 2016, 18, 10727.

12 M. Borgström, E. Blart, G. Boschloo, E. Mukhtar, A. Hagfeldt, L. Hammarström and F. Odobel, J. Phys. Chem. B, 2005, 109, 22928.

13 T. Stergiopoulos, A. G. Kontos, V. Likodimos, D. Perganti and P. Falaras, J. Phys. Chem. C, 2011, 115, 10236.
14 S. P. Mohanty and P. Bhargava, Electrochim. Acta, 2015, 168, 111.

15 T. Stergiopoulos, A. G. Kontos, N. Jiang, D. Milliken, H. Desilvestro, V. Likodimos and P. Falaras, Sol. Energy Mater. Sol. Cells, 2016, 144, 457.

16 A. G. Kontos, T. Stergiopoulos, V. Likodimos, D. Milliken, H. Desilvestro, G. Tulloch and P. Falaras, J. Phys. Chem. C, 2013, 117, 8636.

17 Z. Yu, N. Vlachopoulos, M. Gorlov and L. Kloo, Dalton Trans., 2011, 40, 10289.

18 J. Wu, Z. Lan, J. Lin, M. Huang, Y. Huang, L. Fan and G. Luo, Chem. Rev., 2015, 115, 2136.

19 V. Gondane and P. Bhargava, RSC Adv., 2016, 6, 37167.

20 F. Hao, X. Jiao, J. Li and H. Lin, Nanoscale, 2013, 5, 726.

21 L. Li, E. A. Gibson, P. Qin, G. Boschloo, M. Gorlov, A. Hagfeldt and L. Sun, Adv. Mater., 2010, 22, 1795.

22 P. Qin, M. Linder, T. Brinck, G. Boschloo, A. Hagfeldt and L. Sun, Adv. Mater., 2009, 21, 2993.

23 L. Zhu, H. Yang, C. Zhong and C. M. Li, Chem.-Asian J., 2012, 7, 2791.

24 P. Qin, J. Wiberg, E. A. Gibson, M. Linder, L. Li, T. Brinck, A. Hagfeldt, B. Albinsson and L. Sun, J. Phys. Chem. C, 2010, 114, 4738.

25 Y.-S. Yen, W.-T. Chen, C.-Y. Hsu, H.-H. Chou, J. T. Lin and M. C. P. Yeh, Org. Lett., 2011, 13, 4930.

26 J. Cui, J. Lu, X. Xu, K. Cao, Z. Wang, G. Alemu, H. Yuang, Y. Shen, J. Xu, Y. Cheng and M. Wang, J. Phys. Chem. C, 2014, 118, 16433.

27 P. Qin, H. Zhu, T. Edvinsson, G. Boschloo, A. Hagfeldt and L. Sun, J. Am. Chem. Soc., 2008, 130, 8570.

28 V. Gutmann, Coord. Chem. Rev., 1976, 18, 225.

29 Z. Huang, G. Natu, Z. Ji, M. He, M. Yu and Y. Wu, J. Phys. Chem. C, 2012, 116, 26239.

30 S. Lyu, Y. Farré, L. Ducasse, Y. Pellegrin, T. Toupance, C. Olivier and F. Odobel, RSC Adv., 2016, 6, 19928.

31 F. Wu, J. Liu, X. Li, Q. Song, M. Wang, C. Zhong and L. Zhu, Eur. J. Org. Chem., 2015, 6850.

32 F. Fabregat-Santiago, G. Garcia-Belmonte, I. Mora-Seró and J. Bisquert, Phys. Chem. Chem. Phys., 2011, 13, 9083.

33 J. Bisquert, J. Electroanal. Chem., 2010, 646, 43.

34 F. Fabregat-Santiago, J. Bisquert, E. Palomares, L. Otero, D. Kuang, S. M. Zakeeruddin and M. Grätzel, J. Phys. Chem. C, 2007, 111, 6550.

35 Z. Huang, G. Natu, Z. Ji, P. Hasin and Y. Wu, J. Phys. Chem. C, 2011, 115, 25109.

36 C. E. Housecroft and E. C. Constable, Chem. Soc. Rev., 2015, 44, 8386 and references therein.

37 B. Wenger, M. Grätzel and J.-E. Moser, J. Am. Chem. Soc., 2005, 127, 12150.

38 B. Wenger, M. Grätzel and J.-E. Moser, Chimia, 2005, 59, 123. 39 V. K. Thorsmølle, B. Wenger, J. Teuscher, C. Bauer and J.-E. Moser, Chimia, 2007, 61, 631.

40 T. Stergiopoulos, A. G. Kontos, V. Likodimos, D. Perganti and P. Falaras, J. Phys. Chem. C, 2011, 115, 10236. 